\title{
The Development of English Reading Materials Integrated into Character Values on English Subject through Scientific Approach at Grade XI of MA KM.M Padang Panjang
}

\section{Beniario and Istiqa Sari}

Muhammadiyah University of West Sumatera and School of Foreign Languages Haji Agus Salim Bukittingi

\section{Abstract}

English teachers have difficulty in education character, because they have to explore the materials and to integrate character values [1]. A number of studies have reported on internalizing the character values into instruction materials through conferences, dissemination and workshop. However, little attention is given to English reading

Corresponding Author:

Beniario

beni.ario88@gmail.com

Received: 18 January 2019

Accepted: 24 March 2019

Published: 31 March 2019

Publishing services provided by

Knowledge E

(c) Beniario and Istiqa Sari. This article is distributed under the terms of the Creative Commons Attribution License, which permits unrestricted use and redistribution provided that the original author and source are credited.

Selection and Peer-review under the responsibility of the First ELEHIC Conference Committee.

\section{G OPEN ACCESS} materials integrated in character values to address the problems. A lot of development research has been conducted on the integration character values into instructional materials [2, 3] yet very little applied to instruction reading materials integrated into character values joined by scientific approach. This paper report was to develop the valid, and effective English reading materials integrated into character values based on scientific approach. This development research was ADDIE model. This research was under taken in MA KM Padang Panjang. The research findings are; 1) the instruction materials including of teacher book was 3.28 and student book was 3.26, the effectiveness of instruction materials including of students' activities was 3.43, students' achievement was 71.42 percent and character values was 3.10 developing (began being characterized). To sum up the English reading materials integrated into character values on English subject based on scientific approach was valid and effective.

Keywords: English reading materials, teacher book, student book, character values and scientific approach.

\section{Introduction}

Research development on English reading materials integrated into character values are very salient for supporting the education curriculum based on character building (curriculum, 2013 and 2016 revised), while government has given a good model how to integrate character values into teaching materials such teacher book, student book, syllabus and lesson planning. In fact [4] stress that teacher book and student book used 
for teaching in Padang Panjang only introduced the character values and consisting of two steps in implanting character values; receiving and responding but not until characterization steps.

English teachers have difficulty in education character, especially in internalizing character values in instructional materials, because they have to explore and integrate character values into materials [1]. However, according to a literature review on English reading materials development has become more disseminated globally and importance of pedagogies for English teaching has increased, English reading materials development is still not given enough attention, especially on English reading materials. In order to fill this gap, this paper report was to develop the valid, and the effective English reading materials integrated into character values on English subject through scientific approach in Islamic boarding school of Muhammadiyah Kuliatul Mubalighien (MA.KM) Padang Panjang.

\subsection{The integration of character values into English instructional materials}

Character values is one of education purposes stated in 2013 curriculum. Every purposes reflect the instructional materials presented students' home activities as a model to develop the character values. Integration between character educations in learning should be applied in daily life [1].

A good strategy to develop the character values is to bring his/her home reference in such book, game, and comic into the teaching activities as a model how to play correctly the reference for being his/her activities in the teaching steps described in teaching materials.

Dealing with this, school as a miniature to stimulate the character values and home as a character values practice. To implant the moral values at least the student has ever known, felt, done the moral values as a stimulus. There are three steps in implanting the character values; moral knowing (knowledge about moral), moral feeling (feelings about moral), and moral action (a deed moral) [5].

In general, instructional activities can be generalised into the three parts on 2013 curriculum based on scientific approach, it can be seen from the diagram, as follows:

Furthermore, to internalize the character values into instructional materials has three steps, it can be seen the pyramid, as suggested by Krathwohl.

Pyramid above, explains that character process through teaching activities started from receiving is a own the conscious and will gain knowledge process, responding is 


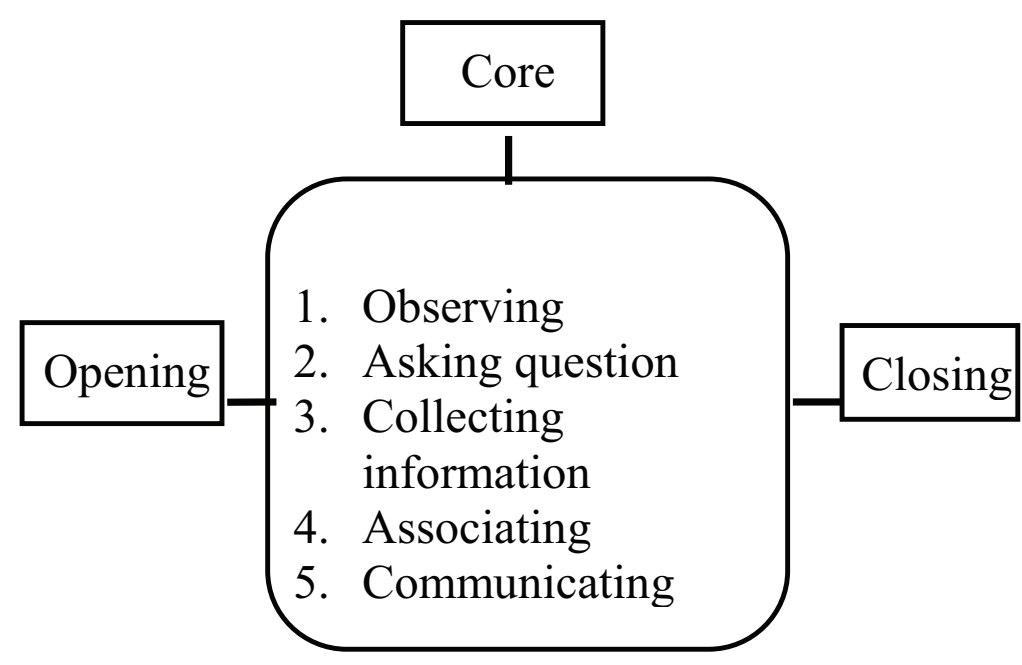

Figure 1: Implant the character values through teaching activities [6].

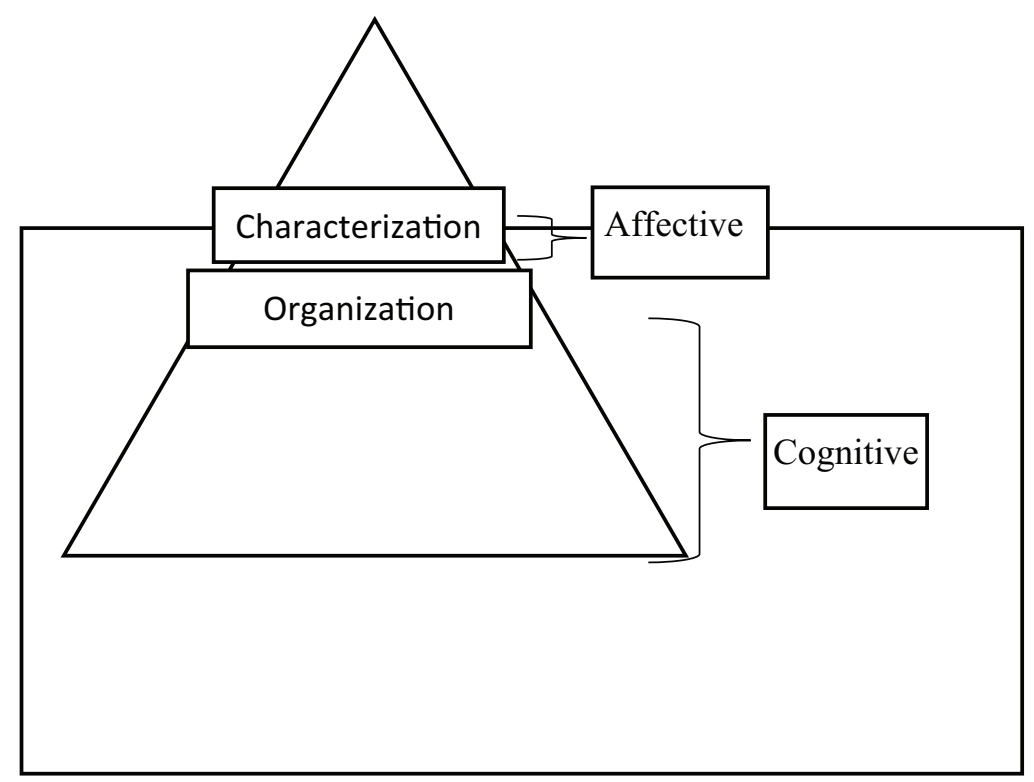

Figure 2: The integration of character values into instructional materials [7].

the interaction of entirely teaching process, valuing is a will to accept the values and to commit to do that values through some stimuli to the values in the classroom, and organization is development concept for being the habit in feeling and acting in daily life, characterization is commitment has been made and practiced then put in the school madding as a control card for the students when they behave beyond the instruction.

\subsubsection{Character values}

Character values in education has been published when the third millennium, it replays again due to morality problems in this nation. It hopes all learning process must be 
related to character values or moral education. The most important main point in character education stated in 2013 curriculum as known a core competence. Government highlighted into 18 values in nation character education, as follows;

TABLE 1: Nation character education [6].

\begin{tabular}{|c|c|}
\hline \multicolumn{2}{|c|}{ Nation character education } \\
\hline 1. Religious & 10. Curiosity \\
\hline 2. Honest & 11. Nationality \\
\hline 3. Tolerant & 12. Peace \\
\hline 4. Disciplined & 13. Appreciative \\
\hline 5. Hard working & 14. Communicative \\
\hline 6. Creative & 15. Peace for welfare \\
\hline 7. Independent & 16. Joy for reading \\
\hline 8. Democratic & 17. Care for environment \\
\hline 9. Caring & 18. Responsible \\
\hline
\end{tabular}

The character values aims to prepare the next golden generation. As a teacher hopes not only transfer knowledge but also give the values through integrating instructional materials. Here, research development focused on particularly character are honest, disciplined, responsible, curious and caring.

\subsubsection{Reading materials integrated into character values in English les- son in MA KM}

Reading materials in 2013 curriculum being a central to develop character values in English teaching. Reading contributes to develop students' character because it can give imagination and appreciate experience as a basis of moral learning, especially on narrative text [1].

In MA KM Padang Panjang reading materials are considered as a basis of moral learning as stated in curriculum such as descriptive, narrative, recount, explanation, analytical exposition, and hortatory exposition.

Literary text often use language to create images in readers' minds; the language enables readers to engage with the text and incorporate their own meanings. with those of the writer [8]. Here, the genre ypes being classified into teaching activities in MA KM Padang Panjang, as follows: 


\section{Descriptive}

Descriptive text describes a thing, person, place or the other thing for being inspired by the students in choosing the materials brought and told concretely. The generic structure are identification and description.

\section{Narrative}

Descriptive text fiction text in the past, its purpose is to entertain or to give a lesson to the readers, the generic structure are: introduction, complicit, resolution, and coda.

\section{Recount}

Recount text is retelling the past event to give the information done by someone or the others, the generic structures are orientation, event 1, 2 and reorientation. In this research were limited from the three genres for being tried out of the teaching materials, as stated in teacher book and student book.

\section{Explanation}

Explanation is a text which tells processes relating to forming of natural, social, scientific and cultural phenomena. Explanation text is to say 'why' and 'how' of the forming of the phenomena. It is often found in science, geography and history text books.

\section{Analytical exposition}

Analytical Exposition is a text that elaborates the writer's idea about the phenomenon surrounding. Its social function is to persuade the reader that the idea is important matter, and to analyze the topic that the thesis/opinion is correct by developing an argument to support it

\section{Hortatory exposition}

Hortatory exposition is a text which represents the attempt of the writer to have the addressee do something or act in certain way. 
Those reading materials used in developing instructional English reading material as stated in teacher book and student book also used scientific approach and combined steps of installing the character values. Those books have stimuli to practice how the character values were internalized through reading activities.

\section{Research Development}

This research was developmental research and used ADDIE model, developed by Reiser dan Molenda around 1990s [9]. Model used five steps: 1) Analysis, 2) Design, 3) Development, 4) Implementation, 5) Evaluation). The ADDIE model can be described as follows:

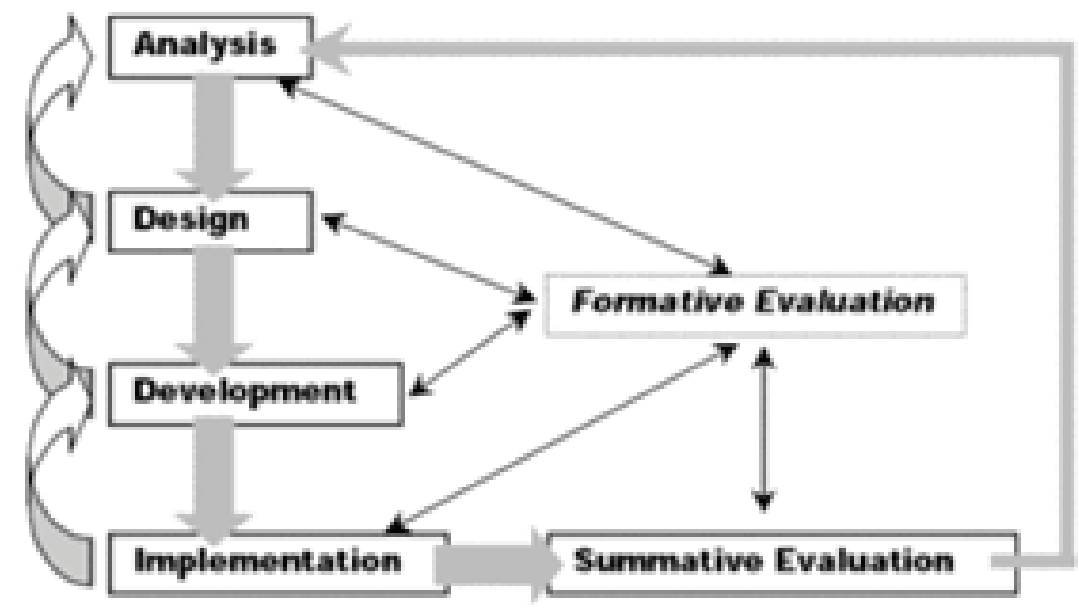

This research was under taken in MA KM Padang Panjang consisted of two classes, namely religion class (ITT) for trying out was effective and science class for applying the reading materials was to see whether effective or not. Validity of the product used 3 validators, and the effectiveness of the product used test and observational checklist.

\section{Discussion and Findings}

\subsection{Analysis}

A guideline for developing the instructional English reading material are to analysis the curriculum used in the MA K.M Padang Panjang, and make a concept of instructional materials. Curriculum analysis was done by interviewing the English teacher and concept of instructional English reading material was done by reading the reference whether book, journal, research result and research report.

Based on the interview done for English teacher at 28 April 2018 in MA K.M Padang Panjang the curriculum used was curriculum 2013 consisted of obligatory and choice 
curriculum, especially on English reading skill has five texts to be discussed during 2017/2018 academic year.

The concept of instructional English reading material was done to support students need, and student characteristics toward the development English reading material. On this step was to know initial students capacity, this relating the ability, vocabulary and English reading had been mastered.

The information gained would help to design what materials should be developed based on students need in installing the character values into instructional materials. The information consisting of instructional aims, topic choice, media, source of teaching and teaching strategies. Those items supported to design the development of English reading materials in MA KM Muhammadiyah Padang Panjang.

\subsection{Design}

The instructional English reading materials analyzed being a draft would guide to develop the instructional English reading materials such teacher book and student book, the source of English reading material designed are curriculum, syllabus, and lesson planning, it consisted of core competency, basic competence, instructional aims and indicators. Those designs can be seen, as follows;

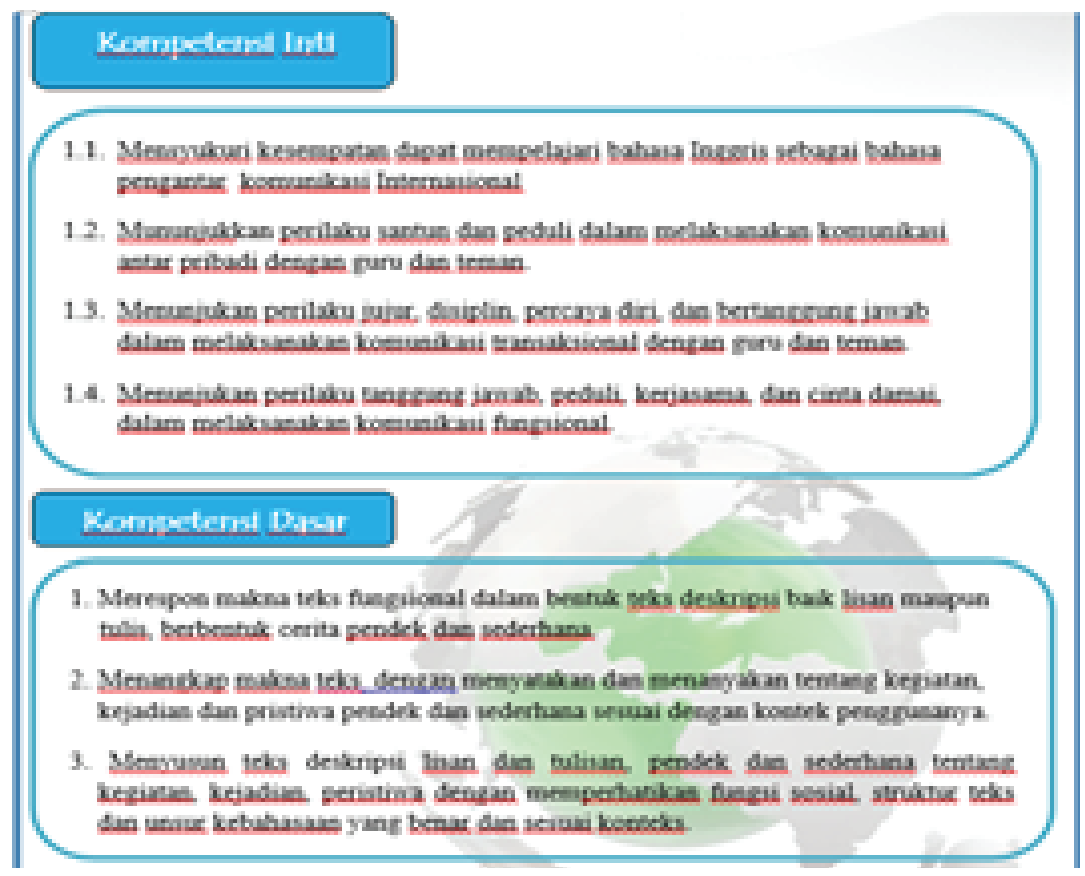

Figure 3: Teacher book. 


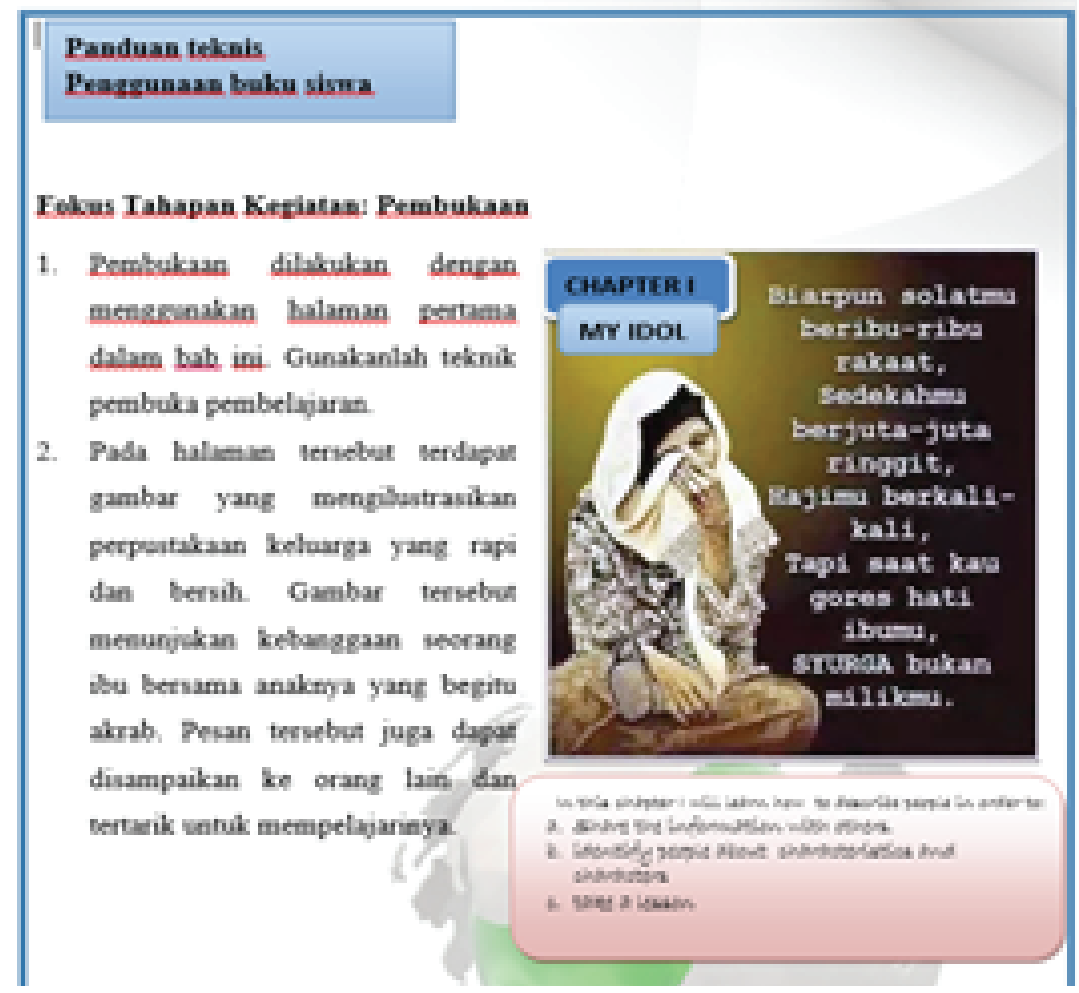

Figure 4: Guideline for teacher.

\subsection{Development}

After drafting the instructional English reading materials consisting of teacher book and student book, the books were validated by validators. In general, there are some assessment indicators in the book designed were contents adequacy, language adequacy, and presentation adequacy.

Here are, the validation result from the validators:

TABLE 2: Teacher book.

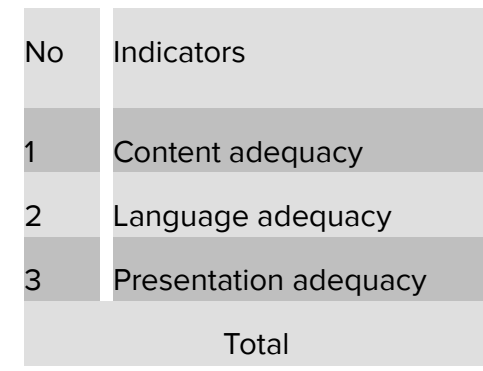

\begin{tabular}{|c|c|c|}
\hline Average & $\begin{array}{c}\text { Deviation } \\
\text { Standard }\end{array}$ & Interpretation \\
\hline 3.33 & 0.25 & Very valid \\
\hline 3.33 & 0.25 & Very valid \\
\hline 3.16 & 0.27 & Valid \\
\hline 3.28 & 0.34 & Very valid \\
\hline
\end{tabular}

Based on the total score of teacher book validation was 3.28 and deviation standard was 0.34 with the category was very valid by using Likert scale (0-4). Those indicators assessment gave the different variants were the average of content adequacy was 3.33 


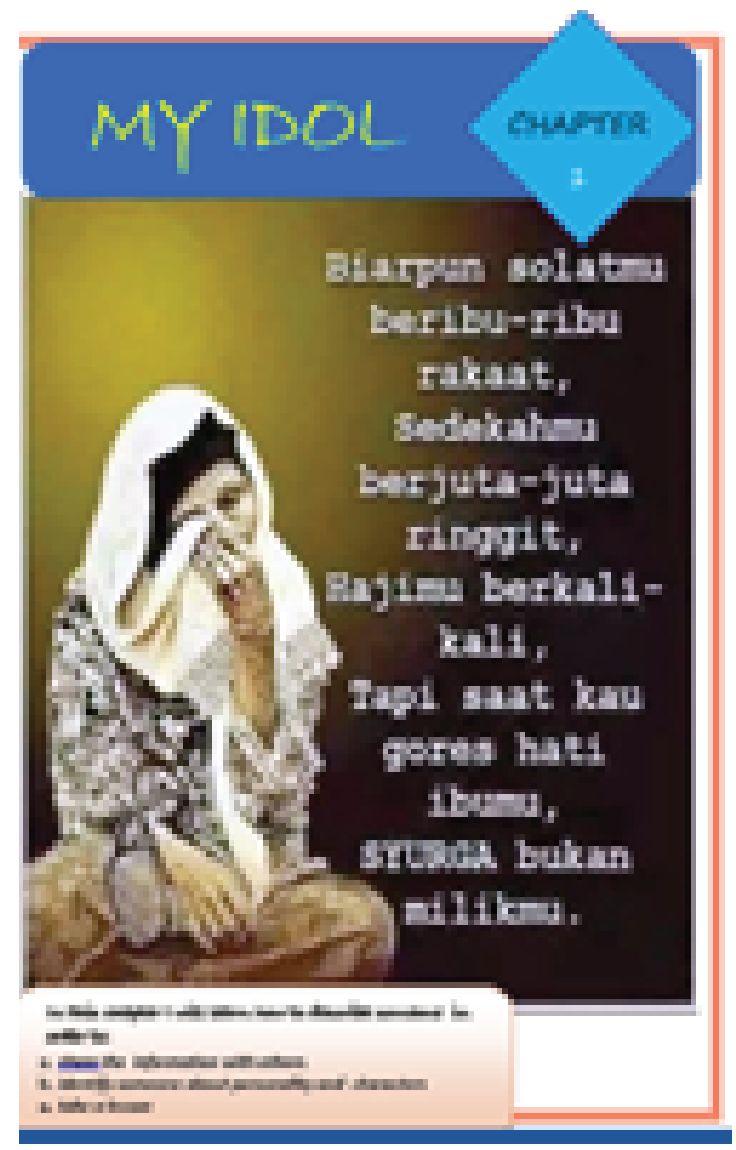

Figure 5: Student book.

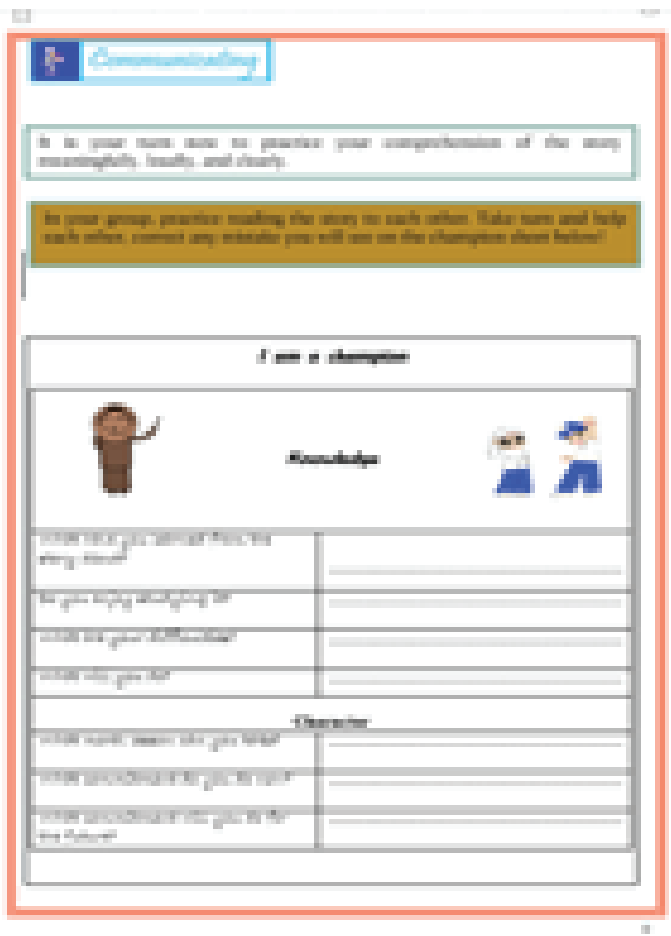

Figure 6: Student book. 
and deviation standard was 0.325 with the category was very valid, the average of language adequacy was 3.33 and deviation standard was 0.25 with the category was very valid, the average of presentation adequacy was 3.16 and deviation standard was 0.27 with the category was valid. It can be concluded that teacher book used for implementing in the classroom was very valid for teaching reading in integrating character values in MA.KM Padang Panjang

TABLE 3: Student book.

\begin{tabular}{l|l} 
No & Indicators \\
\hline 1 & Content adequacy \\
2 & Language adequacy \\
3 & Presentation adequacy \\
& Total
\end{tabular}

\begin{tabular}{|c|}
\hline Average \\
\begin{tabular}{|c|}
\hline .27 \\
\hline 3.4 \\
\hline 3.12 \\
\hline 3.27 \\
\hline
\end{tabular} \\
\hline
\end{tabular}

Deviation
Standard
0.28
0.57
0.24
0.29

\begin{tabular}{c} 
Interpretation \\
\hline Very valid \\
\hline Very valid \\
Valid \\
Very valid
\end{tabular}

Based on the total score of student book validation was 3.27 and deviation standard was 0.29 with the category was very valid by using Likert scale $(0-4)$. Those indicators assessment gave the different variants were the average of content adequacy was 3.27 and deviation standard was 0.28 with the category was very valid, the average of language adequacy was 3.4 and deviation standard was 0.57 with the category was very valid, the average of presentation adequacy was 3.12 and deviation standard was 0.24 with the category was valid. It can be concluded that student book used for implementation in the classroom was very valid for teaching reading in integrating character values in MA.KM Padang Panjang.

\subsection{Implementation}

Implementation was to see whether teacher book and student book effective or not. In implementing the book, there some items would be underlined such as instructional activities, character values and the result of achievement. Here are the result of implementing of developing instructional English reading materials integrated into character values on English subject through scientific approach, as follows;

\subsubsection{Instructional activities}

Instructional activities done by using 3 observers, and they gave a checklist on checklist sheet and wrote whatever was not included in the observational checklist, here are result of observational checklist; 
TABLE 4: Students' activities.

\begin{tabular}{l|l} 
No & Indicators \\
\hline 1 & Opening \\
2 & Core \\
3 & Closing \\
& Total
\end{tabular}

\begin{tabular}{|c|c|c|}
\hline \multicolumn{3}{|c|}{ The average of observational score } \\
\hline Avg 1 & Avg 2 & Avg 3 \\
\hline 3.83 & 3.66 & 3.33 \\
\hline 3.33 & 3.25 & 3.16 \\
\hline 3.5 & 3.41 & 3.41 \\
\hline 3.55 & 3.44 & 3.30 \\
\hline
\end{tabular}

To measure the effectiveness of instructional reading materials was to see the students' activities during the teaching and learning process in opening, core and closing. The average (avg) of activities was 3.43 with the scale (0-4) and it is similar with $\leq$ 75 percent, it means that students' activities in using the instructional material was very dominant from students. Those books has promoted the students to develop their characters by reading the books in learning process. The activities are combined with the steps of installing character values such as 1) observing and receiving, 2) asking question and responding, 3) collecting information and values, 4) associating and organization, 5) communicating and characterization. The five steps teaching as stated in teacher and student book used to guide teacher and student to integrate the character values in learning and teaching process.

\subsubsection{Character values}

TABLE 5: Character values.

\begin{tabular}{c|l|} 
No & Character \\
1 & Honest \\
2 & Disciplined \\
3 & Responsible \\
4 & Curious \\
5 & Caring \\
\hline & \multicolumn{1}{c}{ Total }
\end{tabular}

\begin{tabular}{|c|c|}
\hline \multicolumn{2}{|c|}{ Observers } \\
\hline Observer 1 & Observer 2 \\
\hline 3.04 & 3.04 \\
\hline 3 & 3.19 \\
\hline 3.09 & 3 \\
\hline 3 & 3.14 \\
\hline 3.14 & 3.14 \\
\hline 3.054 & 3.10 \\
\hline
\end{tabular}

Interpretation

Developing

Developing

Developing

Developing

Developing

Developing

The table 5 explains that using instructional English reading materials in integrating character values was 3.10 in scale (0-4). Based on the observational check lists, those characters were to begin to develop for particularly character were honest, disciplined, responsible, curious and caring. Teaching activities integrated into character values was 
a stimulus to embed the character values, it hopes reflect the values when they develop to family and community. Dealing with this, values should be recognized that molarity reflects only a portion of human values [10]. As an instructional English reading materials should give stimuli to develop not only skill, knowledge but also values relating to human values.

The essence of development English reading materials integrated into character values succeeded, but need to force informal education. Dealing with this character of education that focuses on the students' identity development to be smart and having students character needs to be forced through informal and formal education in Leo [11].

\subsubsection{Result of testing}

To measure the success of students' English reading learning used a test. The learning result for pre-test was 58.55 with the category under minimal achievement criteria (KKM) or similar with 38.09 percent, while post-test score was 76.45 with the category upper the minimal criteria or similar with 71.42 percent, while the minimal achievement criteria in MA KM Padang Panjang was 70, it means that the implementation of using English reading materials was effective to integrate character values into instructional materials through scientific approach. Effectiveness learning model of character education through e-comic Using test for measuring students' ability was effective by using test [12].

\subsection{Evaluation}

Validators filled the checklist sheet and they also gave the suggestions for revising the books, and here some suggestions has done to improve the books before implementing, as follows;

TABLE 6: List of revision.

Teacher book
1. Revise the composition
2. Distinguish between indicator and
instructional aims
3. Revise the color in the book
4. Revise the color picture as illustration in the
book

\section{Student book}

1. Revise the grammar

2. Font used must be consistent

3. Add learning book

4. Add the color

5. Interpret the picture again

6 . Find the other example

Sauce: validator suggestion in list checklist for validation 
Evaluation has done to improve the development product from many aspects; content adequacy, language adequacy and presentation adequacy to develop the books integrated into character values on English subject based on the table 6, while the implementation process were corrected directly to English teacher. Finally, using ADDIE model to develop English reading materials has supported to develop this research development.

\section{Conclusion and Recommendation}

This research can be concluded in two aspect, first validation aspects promoted to develop the English reading materials content, language and presentation adequacy. Those books were very valid and already to using in teaching English reading especially at MA KM Padang Panjang, Effectiveness of the books neither teaching process, result of testing nor building the character values. This paper are strongly recommended to English teachers use and redevelop for others subject such as wiring, speaking and listening and suggested to follow the seminar, workshop and others academic activities integrating character values into instructional materials.

\section{References}

[1] Abdurrachman. Faridi. 2014. The difficulties of English Teachers in Installing Character Building through Narrative in Central Java. Unnes. Cotemporary applied science. Vol. No.1. 2 Oktober. ISSN: 208-1365.

[2] Rizadi. Hadi. 2015. The Integration of Character values in the teaching of economics: a case selected high school in Banjarmasin. Universitas Lambung Mangkurat. International Education studies Journal. Vol 8, No 7: 2015. ISSN 1913-9020 E-ISSN 1913-9039

[3] Sardjijo dan Hipzi. Ali. 2017. Integrating Character Building into mathematics and science courses in Elementary school. International Journal of Environmental and science education. Vol. 12, No 6.1547-1552: Look academic Publisher.

[4] Gusmaizal \& Beniario. 2016. Character values in English text book of SMP Padang Panjang in West Sumatera Indonesia. Proceeding Acer-N 2016. ISBN: 978-983-226795-9.

[5] Lickona, Thomas. 2004. Character Matters: Persoalan Karakter, Bagaimana Membantu Anak Mengembangan Penilaian yang Baik, Integritas, dan Kebajikan penting lainya. Jakarta: Bumi Aksara. 
[6] Kemendiknas. 2010. Pembinaan Pendidikan Karakter di Sekolah Menengah Pertama. Jakarta: Kemendikna.

[7] KrathWohl, R. David, dkk. 1964. Taxonomy of Educational Objectives: the Classification of Educational Goals. New York: David McKay Company, Inc.

[8] Knapp. Peter \& Watkins. Megan. 2005. Genre, Text, Grammar: Technologies for teaching and assessing Writing. Autralia: University of New South Wales Press Ltd.

[9] Reiser, R.A. 1987. Instructional technology: A his- tory. In R.M. Gagne (Ed.), Instructional technology: Foundations. Hillsdale, NJ: Erlb

[10] Reiser, R.A., \& Ely, D.P. 1997. The field of educational technology as reflected through its definitions. Edu- cational Technology Research and Development, 45(3), 63-72

[11] Springer. 2009. International handbook of research on teachers and teaching. Part one. Editor. LLC: New York.

[12] Leo, Agung. 2011. Character Education Integration In Social Studies Learning. International Journal of History Education, Vol. XII, No. 2 (December 2011). http: //jurnal.upi.edu/file/08.pdf

[13] Achmad. Buchori1 and Rina, Dwi.Setyawati. 2015. Developing learning model of character education through e-comic in elementary school. International Journal of Education and Research Vol. 3 No. 9 September 2015: PGRI University of Semarang. 